\title{
HOZAMMENEDZSMENT ÉS ÁROPTIMALIZÁCIÓ A HOTELSZEKTORBAN
}

\author{
Fazekas Lajos
}

\begin{abstract}
Absztrakt: Jelen munkámban a szállodaipar müködését alapjaiban megváltoztató folyamatokkal, így a dinamikus árazással, a hozammenedzsmenttel és az ároptimalizációval foglalkozom. Ezen folyamatok az utóbbi évek során komoly hatást gyakoroltak a szállodák müködésére. A hotelek célja az utóbbi években, hogy megfelelő szegmentáció segítségével minden vendég, minden vevő számára ideális ajánlatot tudjanak nyújtani, növelve ezzel a fogyasztók lojalitását, márkahűségét, visszatérési hajlandóságát. A hozammenedzsment rendszerek alkalmazását ma már a hotelek minden részlegére ki kell terjeszteni annak érdekében, hogy az esetlegesen kisebb nyereséget hajtó részlegek más osztályok felé irányítsák a vendégeket, így növelve a teljes tartózkodás során elért haszon teljes mennyiségét. A teljes hotelszektor müködésére is kihat ugyanakkor az online utazásszervezők megjelenése, akik a korábbi utazási irodáktól teljesen eltérő szemlélettel szervezik útjaikat, támaszkodva ennek során azokra a nagy online minősítő rendszerekre, amelyek a magánfelhasználók fogyasztói döntéseire is komoly hatással vannak.
\end{abstract}

\begin{abstract}
The aim of this paper is to deal with those trends which are affecting the whole operation of the hotel industry including dynamic pricing, yield management and price optimisation. These processes had great impact on the operation of the hotels in the last few years. The aims of the operation of the hotels in the last years were to find the ideal offer for all the guests with the help of the segmentation. This way hotels can increase the loyalty and brand loyalty of their customers and their willingness to return to the hotel again. The use of the yield management systems should have been extended to all the parts and departments of the hotel in order to direct the guests between the more and less profitable departments. This way the total realised profit for the whole stay of the guest can be increased. The presence and appearance of the online travel agencies have effects on the whole tourism and hospitality sector because the new actors are organising their offered journeys with a different philosophy. During their work they are using the big databases built by the online ranking systems which have big effect on the guests' decisions as well.
\end{abstract}

Kulcsszavak: szálloda, hozammenedzsment, ároptimalizáció, utazási irodák

Keywords: hotel, yield management, price optimisation, travel agencies

\section{Bevezetés}

A gazdaság más területeihez hasonlóan a hotelszektor szervezetei is azzal a céllal dolgoznak, hogy az általuk nyújtott termékeket és szolgáltatásokat minél nagyobb jövedelmezőségi szint mellett tudják biztosítani a fogyasztók számára. Az EU-28 tagállamainak többségében ez a törekvés sikerrel is jár, hiszen a szabadidös, kulturális és sportszolgáltatások a hozzáadott érték tekintetében az első három húzóágazat között találhatóak (Bácsné Bába et al., 2018). A növekvő komplexitású versenykörnyezet már önmagában is komoly kihívást jelentett a szállodaipar szakemberei és vezetői számára, másrészről pedig a hotelláncok méretének és az egyes hotelek menedzsmentjével kapcsolatos változók számának növekedése megkövetelte egy strukturált és stratégiai szemléletü megközelítés alkalmazását. Erre a helyzetre adott válaszként jelent meg a hotelszektorban a hozammenedzsment, ami eredetileg a légiközlekedési ágazat területén bevezetett koncepció volt. A hozammenedzsmentet általában úgy definiálják, mint az információs rendszerek és 
az árazás alkalmazása annak biztosítására, hogy a megfelelő kapacitás a megfelelő helyen és a megfelelő időben legyen elérhető a jövedelmezőség maximalizálásának érdekében (Smith et al., 1992; Legohérel et al., 2013). A konverziót a két ágazat közötti számos hasonlóság tette lehetővé, mint a kapacitás korlátozott természete, a fogyasztók időben elöre történő foglalása, az alacsonyabb árral történő versengés a kereslet és kínálat egyensúlyában mutatkozó széles eltérések, valamint a készletek romlandósága, ami arra utal, hogy az adott napon kihasználatlan szoba vagy repülőkapacitás nem értékesíthető egy későbbi időpontban (Cross et al., 2011). Elsőként a Marriott hotellánc hozott létre külön hozammendzsment szervezetet és jelentős befektetések árán kifejlesztették az első automatizált hozammenedzsment rendszerek egyikét, ami napi szinten adott kereslet előrejelzéseket és készletkezelési ajánlásokat a hotellánc 160000 szobájára. Az 1990-es évek közepére a hozammenedzsment sikeres implementációja éves szinten 150-200 millió dolláros többletjövedelmet generált a Marriott számára (Marriott-Cross, 2000).

Rövid idő alatt más jelentős hotelláncok is átvették a hozammenedzsment módszertanát, a gyakorlati alkalmazás pedig olyan széleskörüvé vált, hogy a hotel szektorban a hozammenedzsment szétválaszthatatlanul összeforrt a piaci stratégiával (Cross et al., 2009). Az ár kezdettől fogva a szálloda piaci pozíciójának egyik legmeghatározóbb komponense volt, mivel az árak változtatásán keresztül válik lehetővé a hotelek számára, hogy alkalmazkodni tudjanak a különböző jellegzetességekkel rendelkező fogyasztói szegmensek keresletéhez (Cheng et al., 2011; Ivanov, 2014). A kezdetben használt hozammenedzsment modellek még leginkább a szobák árainak igazításaira fókuszáltak, az azóta eltel évek alatt azonban jelentősen megváltozott mind a szállodák müködési környezete, mind pedig a szolgáltatásokat igénybe vevő fogyasztók jellemzői (Ivanov-Zhechev, 2012). A változások legfőbb hajtóerői a digitalizáció területén bekövetkező változások, a big data forradalom, a technológiai eszközök fejlődése által lehetővé tett korábbi kapacitáskorlátok megszünése és az információk szinte korlátlan és azonnali áramlása a fogyasztók között. A folyamatosan és gyors ütemben változó piaci környezetben a sikeresség alapját az képezi, hogy a szervezetek milyen gyorsan képesek alkalmazkodni a müködési környezet változásaihoz (Bácsné Bába, 2014).

\section{Anyag és módszer}

Tanulmányomban szeretném bemutatni, hogy a hotel szektor és a kapcsolódó szakirodalom alapján jelenleg milyen trendek figyelhetők meg az ágazat három kulcsfogalma: a szegmentáció, az ároptimalizáció és a hozammenedzsment kérdéskörében. Jelen vizsgálati témakörök alapos és kiterjedt szakirodalmi áttekintését nyújtja, ami lehetővé teszi a releváns nemzetközi szakirodalom legfrissebb fejleményeinek áttekintését, adaptálását a hazai viszonyokra.

Elsőként a szegmentáció fogalomkörét tekintem át. Ezt követően a hotelipar esetében is egyre nagyobb szerephez jutó digitális forradalom aktualitásait és lehetőségeit vizsgáljuk a hozammenedzsment szempontjából. Ez a jelenség már közvetlen hatással van az ároptimalizáció folyamatára is. Végezetül a cikk keretében részletesen is foglalkozom a hozammenedzsment kérdéskörével is. 
Jelen cikk célja, hogy a vizsgált kutatási terület rendelkezésre álló szakirodalmi forrásainak, mint szekunder adatbázisnak a felmérésével segítse elő a téma alaposabb megismerését. Kothari (2004) szerint a szekunder adatok feldolgozása a kutatás egy megkerülhetetlen, költséghatékony módja, amely segítségével jó időgazdálkodás mellett megismerhetjük az egyes kutatási területek legfrissebb nemzetközi fejleményeit és megalapozhatjuk saját primer kutatásainkat. A szekunder adatfeldolgozás során ugyanakkor kellő körültekintéssel kell összeállítanunk a feldolgozott információ körét, hogy azok hitelesek és érvényesek maradjanak.

\section{Az eredmények értékelése}

\subsection{Fogyasztói szegmentáció}

A szegmentáció során a fogyasztókat igényeik és elvárásaik szerint olyan csoportokba osztjuk, ahol a csoportok tagjaira azonos tulajdonságok jellemzőek (Ivanov, 2014). Ilyen jól definiált szegmens például az úgynevezett LOHAS (Lifestyle of Health and Sustainability) fogyasztói csoport, akik fenntarthatósággal és környezettudatos fogyasztással kapcsolatos értékeik (Szakály et al., 2017) miatt valószínüleg elönyben részesítenek olyan hoteleket, ahol a szolgáltatások a zöld turizmus (Gavrilović-Maksimović, 2018) irányvonal szellemében vannak kialakítva. Az alapvető cél ennek során az, hogy felismerjük, az egyes csoportok hogyan reagálnak a szolgáltató egység által nyújtott különbözö ár- és termékcsomagokra, felmérjük vásárlásaik okát és az ebből következő fizetési hajlandóságukat. A turizmus szektor esetében ez a folyamat kiemelkedően nehéznek bizonyul, mivel minden célállomás és idegenforgalmi egység különböző tulajdonságokkal, környezeti tényezőkkel és stratégiával bírhat (Rondan-CatalunaRosa-Diaz, 2014). A fogyasztói csoportok felbontására a szállodák különböző szempontokat vehetnek alapul.

A belső szegmentáció közvetlenül a hozammenedzsment irányítása alatt áll és olyan tényezők függvényében hoznak árazási döntéseket, mint a piaci helyzet, a fontosabb lokális események vagy a szezonalitás (Kim et al., 2016). Több idetartozó döntési faktor közül a szoba- és szolgáltatásár legáltalánosabb differenciáló tényezője a foglalási idő (Schütze, 2008). Elterjedt stratégia a hoteleket vezető szakemberek körében, hogy olyan időszakok esetén, amikor magas kihasználtság várható, a szobák egy részét nem bocsátják azonnal rendelkezésre. Ennek oka a foglalási időszak azon sajátságában található, hogy az időszak elején jelentős kereslet mutatkozik az alacsony áron elérhető szobákra, a későbbiekben azonban, ahogy a foglalási idő egyre közelebb kerül az igénybevétel időpontjához, magasabb áron is értékesíthetővé válnak ugyanazok a szobák. A hozammenedzsment feladat ebben az esetben a legnagyobb jövedelmezőséget jelentő egyensúlyi ár megtalálása, amivel egyrészt nem marad kihasználatlan kapacitás, ugyanakkor nem kerülnek túl alacsony áron értékesítésre a rendelkezésre álló szobák sem (Aziz et al., 2011; Vives et al., 2018). 
További széles körben használt eljárás az árkorlátok alkalmazása. Ezek olyan szabályok, amelyek segítségével szegmentálni lehet a keresletet és különböző árakon lehet felkínálni szolgáltatáscsomagokat az egyes csoportok számára. Az egyes korlátok alapját képezheti például a foglalási csoport nagysága, a foglalt idő hossza, hogy lemondható-e a foglalás díjmentesen vagy sem, a szoba típusa vagy a tartalmazott többletszolgáltatások (például reggeli, wellness használat) száma (Liu et al., 2014). A korlátok egy része, például amelyek a szoba típusán alapulnak, tetszőlegesen átléphetőek a fogyasztók részéről fizetési hajlandóságuk függvényében, ezért ezeket a fogyasztók szempontjából önszegmentáló korlátoknak nevezzük (Narangajavan et al., 2014). Más korlátok, például a hüségprogram keretében vagy bizonyos szervezetek tagjainak nyújtott támogatások a vendéglátó egység kontrollkörébe tartoznak, így a fogyasztók semmilyen módon nem tudják az ezek által nyújtott áropciókat igénybe venni, ha nem rendelkeznek a jogosultság feltételeivel. A hozammenedzserek ugyanakkor azt is egyre inkább kezdik felismerni, hogy a fogyasztók elönyösnek tekintik a rugalmas termékcsomagokat, ezért néhány olyan új stratégia is kezd megjelenni ezen a területen, ami nagyobb döntési teret ad a vendégek számára. Az egyik ilyen megközelítés a standby upgrade reservation nevü foglalási opció, ami szélesebb körü vagy magasabb szintü szolgáltatás igénybevételét teszi lehetővé az eredeti foglaláshoz képest az érkezés időpontjában, amennyiben a szálloda rendelkezik a megfelelő szabad kapacitással, ugyanakkor ezeket a szolgáltatásokat nem kell előzetesen lefoglalni vagy kifizetni (Yilmaz et al., 2017). Egy másik ehhez hasonló megközelítés az opcionális árazási stratégia, ahol az alapterméket (szoba) egy kiegészítő szolgáltatásokat is tartalmazó termékcsomagba helyezik, ahol az alaptermék ára alacsonyabb, mint amilyen önmagában lenne. A megnövekedett jövedelmezőséget a kiegészítő termékek magasabb ára fogja eredményezni, így növelhető a többletszolgáltatásokat jobban preferáló vendégek csoportjából származó hozam (De Toni et al., 2017).

A fogyasztói csoport felosztható továbbá az utazás célja alapján is üzleti és kikapcsolódási céllal utazó személyekre. A két csoport között számos eltérés mutatkozik, például a preferált szállodák tulajdonságaiban és felszereltségében (Kashyap-Bojanic, 2000), továbbá különbség lehet a hotelválasztási szempontok (Yavas-Babukas, 2005), vagy akár az alkalmazott információkeresési stratégiák között is (Jones-Chen, 2011). Az újabb kutatási irányok többek között olyan különbségekre is rámutatnak, mint a manapság egyre jelentősebb tényezőnek számító fogyasztók által generált tartalmak eltérö hatása a két csoport foglalási szokásaira (Noone-McGuire, 2014). További érdekes tény, hogy a szállodaszolgáltatásokat igénybe vevő személyek átlagosan 4\%-kal alacsonyabb elégedettséget mutatnak, ha üzleti céllal utaznak a kikapcsolódási célú utazásokhoz képest. Az ilyen különbségek okainak feltárása azért jelentős az egész szektor számára, mert az alacsonyabb elégedettség alacsonyabb értékeléseket is jelent, így az elsősorban üzleti célú utazásokat kiszolgáló szállodák hátrányba kerülhetnek a fogyasztói értékelések alapján rangsoroló online keresési felületeken, ami hosszú távon jelentős veszteséget eredményezhet (Radojevic et al., 2018). 


\subsubsection{Hotel szegmentáció}

Mint látható, számos lehetőség kínálkozik a hozammenedzsment szakemberei számára, hogy különböző fogyasztói csoportokat és hozzájuk tartozó különböző árprofilokat alakítsanak ki a teljes fogyasztói bázisból. Ugyanakkor fontos feladat az is, hogy a szálloda müködési feltételeit adó piaci környezetet is szegmentálják, vagyis meg kell határozniuk, hogy az adott üzleti egység milyen szerepet kíván betölteni az adott piacban és hova akarja pozícionálni magát a versenytársakkal szemben.

A csillagok száma a legnagyobb arányban ismert szegmentációs szempont a fogyasztók körében (Dioko et al., 2013) annak ellenére, hogy az elmúlt években többen is megkérdőjelezték (Nunez-Serrano et al., 2014) a csillag alapú értékelési rendszer minőségi standardként való alkalmazhatóságát. Az interneten megjelenő, fogyasztók által generált tartalmakra és online értékelésekre alapozott elemzések azonban továbbra is megerősítik, hogy a szállodák szolgáltatásának minőségére lehet következtetni a csillag alapú értékelési rendszerbe történő besorolás alapján (Fang et al. 2016), bár az eredményeket némileg torzítja, hogy a fogyasztók értékelései nem függetlenek az ártól (Fernandez-Barcala et al., 2010), emiatt a magasabb kategóriájú hotelek magasabb árai magasabb fogyasztói értékeléseket is vonnak maguk után (Martin-Fuentes, 2016).

\subsection{A digitális forradalom hatása az értékesítésre}

A digitális forradalom nyomán kialakuló világban a hotelek legfontosabb kérdésévé az értékesítési csatornák helyes kombinációjának megválasztása kezd válni. Az internet megjelenése alapjaiban változtatta meg a hotel és turisztikai szektor világát, markáns választóvonalat emelve a hagyományos és az új értékesítési utak között. Az internetes és mobiltechnológiák fejlődése eljutott arra a pontra, ahol az általuk nyújtott vásárlási lehetőségek köre és színvonala kezdi megkérdőjelezni a hagyományos csatornák, például az utazási ügynökségek létezésének okát (Morosan, 2014). Hagyományos csatornák alatt olyan értékesítési utakat értünk, melyek hotelek és különböző turisztikai egységek szolgáltatásainak és termékeinek terjesztését segítik, közvetítőként lépve fel a szolgáltató és a felhasználó között (Law et al., 2015). A személyes interakció szinte az egyetlen olyan jellegzetesség, amit az online csatornák egyelöre nem tudnak pótolni vagy felülmúlni, ami az emberi kontaktust a hagyományos csatornák létezésének legerősebb indokává teszi. Ez a fajta igény egyre inkább csak bizonyos speciális fogyasztói csoportok körében jelenik meg, mint például a hosszabb szervezett utakat kereső személyek, az üzleti céllal utazók bizonyos csoportjai, az alacsony jövedelemmel rendelkező személyek, idősek (akik nem mozognak olyan magabiztossággal az internet világában, mint a fiatal generációk) és olyan fogyasztók, akik komplex termék- és szolgáltatáscsomagokat vásárolnak, mint például a nászutasok (Gronflaten, 2009; Del Chiappa, 2013). Annak ellenére, hogy 2015-ben már a globális foglalások több mint 50\%-a történt valamilyen online felületen keresztül (Hospitality, 2015), ez a szám egyúttal azt is jelenti, hogy körülbelül $40-45 \%$ továbbra is a hagyományos csatornákon keresztül 
lett értékesítve, ami egyértelművé teszi, hogy ezeket sem hagyhatja figyelmen kívül egyetlen hozammenedzsmenttel foglalkozó szakember sem.

További nagyhatású változást jelentett az elmúlt évtizedben az online utazási irodák (Online Travel Agency - továbbiakban: OTA) megjelenése és rohamos térnyerése. Ezek az oldalak közvetlen hozzáférést biztosítanak a fogyasztók számára a különböző turisztikai termékekhez és szolgáltatásokhoz (Xiang et al., 2015), ami elméletileg szükségtelenné teszi a közvetítők szerepét a fogyasztók és a szolgáltatók között. Az angolul „,deintermediarization”-nek elnevezett jelenség jelenleg a turizmus- és vendéglátóipar egyik aktuális kérdése, mivel alapjaiban változtatja meg a korábbi értékesítési láncolatot, ahol közvetítők segítségével jutottak el a felkínált szolgáltatások a fogyasztókhoz (Oskam-Zandberg, 2016). Mások ugyanakkor azon a véleményen vannak, hogy a legnépszerübb OTA-k, mint az Expedia vagy a Booking.com kezdenek hasonló közvetítő szerepet betölteni, mint korábban az utazási irodák, és ezt a folyamatot a reintermediarization jelenségének hívják (Law et al., 2015). A hotelek vezetőinek egyúttal azzal a helyzettel is szembesülniük kellett, hogy az OTA-k egyre növekvő térnyerése egyre erösebb alkupozíciót is jelentett számukra, ami hátrányos helyzetet jelentett a szállodák számára. Részben erre adott válaszként, részben pedig a digitális forradalom által bekövetkező változásokra reagálva jöttek létre a Brand.com jellegü értékesítési csatornák. Ezek olyan online felületek, amiket a szállodák maguk fejlesztenek és ezeken keresztül a potenciális vendégek foglalásokat tehetnek, valamint tájékozódhatnak az adott hotel szolgáltatásaival és áraival kapcsolatban (Kimes-Wirtz, 2015). A kezdeményezés sikerességét mutatja, hogy 2016 első felében a TravelClick kimutatásai alapján az Egyesült Államokban a hotelek jövedelmezőségének mindössze 16\%-át adták az OTA-n keresztül történő foglalások és 35\%-ot tettek ki a saját fejlesztésü Brand.com oldalakon keresztül történő értékesítések (TravelClick, 2016). Érdemes ugyanakkor azt is megjegyezni, hogy mindkét említett csatorna a modern foglalási felületek közé tartozik, mutatva az ilyen értékesítési csatornák további térnyerését és részben mégis igazolva azoknak a véleményét (Oskam-Zandberg, 2016) akik a modern értékesítési utak további és még jelentősebb térnyerésére számítanak.

Összefoglalva elmondhatjuk, hogy mind a hagyományos, mind pedig az újabb értékesítési csatornák jelentős piaci hatóerővel rendelkeznek, így a menedzser feladata a legjobb csatorna kiválasztásáról a megfelelő csatornamix kialakítására változik. Ezt nehezíti az a tény, hogy ezek a csatornák egymással párhuzamosan és egymással versengve vannak jelen, valamint különbözö költségeik és előnyeik vannak (Tan-Dwyer, 2014). A hagyományos csatornák alacsonyabb költségekkel járhatnak, ugyanakkor egyre szükülő fogyasztói réteget képesek megszólítani (Law et al., 2015), a modern csatornák esetében pedig a csatornamix kialakítása igényel komoly mérlegelést. Beritelli-Schegg (2016) szerint a Brand.com csatorna 10-15ször olcsóbb, mint az OTA-k használata, ugyanakkor messze nem rendelkezik olyan jelentős marketingerővel, mint az OTA-k.

A hotelek és az OTA-k kapcsolatát vizsgálva röviden mindenképpen ki kell térni az árgarancia (angolul: rate parity) kérdésére. Az árgarancia problémája ma már nem pusztán gazdasági kérdés, hanem komoly jogi viták tárgya is. A szabályozás 
fenntartása mellett érvelők véleménye szerint a minden értékesítési csatornára kiterjedő árgarancia segít fenntartani a fogyasztókban az ár igazságosságának érzetét, valamint a hotelek számára segíthet brandjük értékének fenntartásában (Choi-Matilla, 2009; Le et al., 2018), mivel az OTA-k és más közvetítők felületén megjelenő alacsonyabb árak képesek a brand devalvációját eredményezni (Berezina et al., 2016). A szabályozást kritizálók legtöbbször arra hivatkoznak, hogy az árgarancia csökkenti az iparágban a versenyt és ezáltal magasabb árakat eredményez, valamint megakadályozza a hoteleket abban, hogy szabadon alakítsák árstratégiájukat az összes értékesítési csatornán keresztül, aminek következtében csökken a szükebb fogyasztói csoportokra irányuló, fókuszáltabb stratégiák lehetősége is (Law et al., 2007; Mohammed et al., 2017). Jelentős eltérések vannak a jogi szabályozás területén is, például az Egyesült Államokban létezik szűk és széles értelemben vett árgarancia, Európán belül pedig komoly eltérések mutatkoznak az egyes országok között az árgarancia teljes eltörlésétől kezdve (például Franciaország, Olaszország) a csak bizonyos OTA-kat érintő részleges bevezetésig (például Németország), továbbra is nyitva hagyva a kérdést a szállodaipar szakemberei számára az árgarancia szükségességéről (Nicolau-Sharma, 2018).

A megváltozó versenykörnyezet számos új tényező figyelembevételét teszi szükségessé a megfelelö hozammenedzsment stratégia kialakítása során, de az új szempontok nem változtatnak azon a tényen, hogy a megszülető döntések egyik kulcspontja továbbra is a megfelelő ároptimalizáció és árstratégia kialakítása. A továbbiakban ezt a két elemet kívánom részletesebben bemutatni.

\section{3. Ároptimalizáció és árstratégia}

Az ár a rövid távú taktikai és a hosszú távú, stratégiai távlatú döntések esetében is fontos szerepet játszik. A modern hozammenedzsment rendszerek napi rendszerességgel adnak árjavaslatokat, amelyek mögött azonban rendkívül komplex változócsoportok és számítások húzódnak meg. A megfelelő árszint kiválasztása bizonyos szempontból egy reakció a fogyasztók valamilyen vélt jövőbeni vásárlási viselkedésére. Ennek leggyakrabban használt modellje a kereslet függvény, amivel meghatározhatjuk a fogyasztó fizetési hajlandóságát és a kereslettől függő árrugalmasságot (Shy, 2008). A kereslet elörejelzés a hozammenedzsment egyik legfontosabb feladata. Az adott hotel jellemzőinek függvényében különböző aggregációs szintủ előrejelzéseket tehetünk. A teljesen aggregált elörejelzés a hotel egészére szolgáltat keresletmutatókat, de legtöbbször érdemesebb kisebb kategóriákra (például különböző szobatípusok) fókuszáló előrejelzéseket tenni, mivel ezek pontosabb eredményekkel szolgálnak és később, amennyiben szükséges, ezeket összefésülve is lehet a szálloda egészére vonatkozó adatokat kapni (Bandalouski et al., 2018). Az elörejelzésekre felhasznált tényleges modelleket tekintve három nagy típust lehet elkülöníteni, melyek közül a legrégebbiek az idősor alapú elemzések, amik csak múltbéli adatokat használnak fel, mint például a foglalások száma egy adott napon egy megelőző időszakban. A fejlett modellek a meglévő foglalások mellett már jövőbeli változásokkal és kimenetekkel is számolnak. Ezek között megkülönböztetünk additív modelleket, amik szerint az 
adott napra már meglévő foglalások függetlenek a foglalási napon a jövőben ténylegesen bekövetkezö foglalások számától, és multiplikatív modelleket, amik azt feltételezik, hogy a már meglévő foglalások befolyásolják a jövőbeli teljes foglalások számát egy adott foglalási napon. A legpontosabb elörejelzéseket a két megközelítést vegyítő harmadik csoport, a kombinált modellek adják (Lee, 2018).

A kereslet meghatározása után a következő lépés az erre alapozott árstratégia megformálása. Az internet elterjedése és a technikai eszközök fejlödése az elmúlt évtized során általánossá tette a dinamikus árazási modellek elterjedését. A dinamikus árazás kulcsfogalmai a flexibilitás és a naprakészség, például egy adott szállodában ugyanaz a szoba más napokon más árakért válik elérhetővé az elöre jelzett kereslet vagy a szálloda hosszabb távú stratégiájának megfelelően (https://www.xotels.com/en/glossary/dynamic-pricing). Az árral kapcsolatos döntések mögött többféle megfontolás is állhat. Kereslet alapú árazás esetén a korlátozott kapacitás ténye miatt a hotelek folyamatosan változtatják az egyes termékkategóriákra vonatkozó áraikat a hozam maximalizálása érdekében (Wang et al., 2015). A költségalapú árazás a folyamatosan változó marketingköltségek vagy a technikai újításokba való invesztálás miatt lehet jó megoldás a hozammenedzsment teljesítményének növelésére (Enz et al., 2015). A piaci penetrációt célzó árazási módszerek keretében az árak szándékosan alacsony szinten vannak tartva, ami leginkább a fogyasztói bázis kiszélesítését vagy új versenytársak betörésének megakadályozását szolgálja (Skripak, 2016). Ennek ellentétje a piaci lefölözésnek is nevezett árstratégia, ami magasabb árakon kínálja a termékeket és szolgáltatásokat. Ez föleg keresleti csúcsidőszakok esetén alkalmazott módszer (Kotler, 2015).

Számos egyéb modell létezik, beszélhetünk többek között termékcsomagok alapján kialakított árazásról, pszichológiai árazásról és promóciós céllal meghatározott árstratégiáról is (Rafiei et al., 2013; Boz et al., 2017; Mill-Morrison, 2009). A különböző árstratégiák célja a versenyelőny megszerzése és a fogyasztói bázis kiszélesítése a hotel piaci szegmensében. Ugyanakkor fontos, hogy a hotelek saját üzleti egységükön belül is megvizsgálják az alternatív stratégiák hatékonyságát, amit a hagyományos és új típusú teljesítmény mutatók együttes használatával érhetnek el (Zsidó-Fenyves, 2015). Az egyes módszerek hatékonysága, valamint egymással és egyéb nem áralapú hozammenedzsment stratégiákkal való kapcsolata a kutatások fontos kérdése (Nair, 2018).

A dinamikus árazás a fogyasztók szempontjából is vizsgálandó kérdés, mivel közvetlen hatással lehet a referenciaárra és az árak észlelt méltányosságára. A referencia ár egy olyan érték, ami alapján a fogyasztó eldönti, hogy az adott szolgáltatás a felkínált áron méltányos-e vagy sem (Viglia et al., 2016). A referenciaár forrása lehet korábbi tapasztalat, hogy milyen árakon jutott hozzá a fogyasztó az adott termékhez, illetve jelenlegi viszonyítási pontok, például más versenytársak által kínált hasonló termékek és szolgáltatások árai (Melis-Piga, 2017). A korábbi tapasztalatok esetében elmondható, hogy a múltban tapasztalt legalacsonyabb árak nagyobb hatással vannak a kialakuló referenciaárra, mint a tapasztalt legmagasabb értékek, időbeli sorrendjüket tekintve viszont nem tisztázott a kérdés, hogy a legkorábbi vagy a legújabb árak befolyásoló ereje a nagyobb (Viglia 
et al., 2016). A hozammenedzsmenttel kapcsolatos döntések meghozása során fontos szem elött tartani, hogy a dinamikus árazás alkalmazása során bekövetkező árváltozások milyen reakciókat váltanak ki a fogyasztókból. Az eddigi vizsgálatok egyértelmü kapcsolatot mutatnak az észlelt méltányosság és a foglalási szándék között, valamint eredményeik alapján az is elmondható, hogy a fogyasztók hajlandóak elfogadni az árak változását, amennyiben ezt indokoltnak érzik és nem sérti az általuk kialakított referenciaárat (Jiang et al., 2018).

\section{4. Összegzés}

A hozammenedzsment a légiforgalmi nagyvállalatok módszertanából átvett gyakorlati modell, melyet az 1990-es évek elején kezdtek el használni a hotel- és szállodaipar legnagyobb képviselői. Az azóta eltelt közel 30 év alatt a szálloda és a turisztikai ipar szétválaszthatatlanul összefonódott a hozammenedzsment fogalmával. A kezdeti időszakban még legnagyobb részben rövid és középtávú döntésekkel foglalkoztak a szakemberek, mára azonban egyre inkább stratégiai és vezetöi szerepkör jellemzi feladataikat. Ennek egyik oka az internet elterjedése és az ezzel párhuzamosan zajló technikai fejlődés, ami alapjaiban alakította át a szállodaipar piaci és versenykörnyezetét. Az új feltételekre reagálva a hozammenedzsment szélesebb perspektívákat kezdett felvenni, kibővítve a külső és belső szegmentáció szempontjait, és tovább lépve a múltra alapozott elörejelzésekről olyan prediktív módszerekre, amik már a jövőt is számításba veszik. Ezzel párhuzamosan folyamatosan fejlődnek az árazási stratégiákkal kapcsolatos gyakorlatok is, melyek az eredeti keresletalapú ármeghatározáson túl más stratégia célokat is figyelembe vesznek az ároptimalizáció során.

A szállodaipar vezetői és szakemberei egyúttal kezdik felismerni a fogyasztók szolgáltatókkal kapcsolatos interakciójában bekövetkező változásokat is. Az OTA-k megjelenése jelentős változást hoz az értékesítési csatornákban, előrevetítve a hagyományosabb csatornák fokozatos térvesztését. A kérdést tovább árnyalják a jogszabályokban mutatkozó regionális és országos különbségek, illetve a fogyasztói tartalmak hatásának folyamatos erősödése, ami elötérbe emel olyan kérdéseket is, mint a referenciaár vagy az észlelt méltányosság.

A jövőben tovább fog folytatódni a hozammenedzsment fejlődése és egyre szorosabb integrációja a szállodaiparral. Erre a trendre utal a Teljes Hotel Hozammenedzsment nevü koncepció megszületése, amelynek keretében a hozammenedzsment módszereit kiterjesztenék a szobákon túl a hotelek minden jövedelemgeneráló egységére (Noone et al., 2017; Zheng-Forgács, 2017). A teljes hotel hozammenedzsment megvalósulása a különböző müködési egységek tevékenységét egy közös irányelv alá rendelné, ami jelenetős lépés lenne a hosszú távú stratégiák megvalósíthatóságának területén. Jelentős befolyással bírhat a közeljövőben az ügyfélélettartam érték is, ami az egyes fogyasztók által generált kereslettel kapcsolatos, egész életre kivetített predikciókat kíván adni. A Customer Lifetime Value modellek célja, hogy a fogyasztók minél több olyan attribútumát felhasználja, ami hatással van a szálloda jövedelmezőségére az egyén fogyasztásától kezdve az általa képviselt reklámértékig és ezeket hosszú távú értékalgoritmusokba 
integrálja (Lew, 2017; Castéran et al., 2017; Yoo et al., 2018). Az elgondolás kapcsolódik a digitális korszakban központi jelentőséggel bíró perszonalizáció gondolatához, mivel a pontosabb és hosszabb távú elörejelzések részletesebb termék- és szolgáltatáscsomagok személyre szabását teszik lehetővé a jövőben.

\section{Irodalomjegyzék}

Aziz, H. A., Saleh, M., Ramsey, M. H., ElShishiny, H. (2011): Dynamic room pricing model for hotel revenue management systems. Egyptian Informatics Journal, 12 (3): 177-183.

Bácsné Bába É. (2014): Változásmenedzsmenthez kapcsolódó reakció idő vizsgálatok = Study of reaction time in change processes. VIKEK Közleményei, 6 (2): 66-74.

Bácsné Bába É., Balogh R., Bács Z., Fenyves V., Dajnoki K. (2018): Sportszolgáltatások keresleti, kínálati oldalának elemzési lehetőségei. Studia Mundi-Economica, 5 (3): 19-33.

Bandalouski, A. M., Kovalyov, M. Y., Pesch, E., Tarim, S. A. (2018): An overview of revenue management and dynamic pricing models in hotel business. RAIRO-Operations Research, 52 (1): 119-141.

Berezina, K., Semrad, K. J., Stepchenkova, S., Cobanoglu, C. (2016): The managerial flash sales dash: Is there advantage or disadvantage at the finish line? International Journal of Hospitality Management, 54: 12-24.

Beritelli, P., Schegg, R. (2016): Maximizing online bookings through a multi-channel-strategy: Effects of interdependencies and networks. International Journal of Contemporary Hospitality Management, 28 (1): 68-88.

Boz, H., Arslan, A., Koc, E. (2017): Neuromarketing aspect of tourısm pricing psychology. Tourism Management Perspectives, 23: 119-128.

Castéran, H., Meyer-Waarden, L., Reinartz, W. (2017): Modeling customer lifetime value, retention, and churn. In: Homburg, C., Klarmann, M., Vomberg, A. (szerk.): Handbook of Market Research, Springer International Kiadó, 1-33.

Cheng, C. K., Li, X. R., Petrick, J. F., O'Leary, J. T. (2011): An examination of tourism journal development. Tourism Management, 32 (1): 53-61.

Choi, S., Mattila, A. S. (2009): Perceived fairness of price differences across channels: the moderating role of price frame and norm perceptions. Journal of Marketing Theory and Practice, 17 (1): 3748.

Cross, R. G., Higbie, J. A., Cross, D. Q. (2009): Revenue management's renaissance: A rebirth of the art and science of profitable revenue generation. Cornell Hospitality Quarterly, 50 (1): 56-81.

Cross, R. G., Higbie, J. A., Cross, Z. N. (2011): Milestones in the application of analytical pricing and revenue management. Journal of Revenue and Pricing Management, 10 (1): pp. 8-18.

De Toni, D., Milan, G. S., Saciloto, E. B., Larentis, F. (2017): Pricing strategies and levels and their impact on corporate profitability. Revista de Administração (São Paulo), 52 (2): 120-133.

Del Chiappa, G. (2013): Internet vs Travel Agencies: the perception of different group of Italian online buyers. Journal of Vacation Marketing, 19 (1): 55-66.

Dioko, L. A., So, S. I. A., Harrill, R. (2013): Hotel category switching behavior-Evidence of mobility, stasis or loyalty. International Journal of Hospitality Management, 34: 234-244.

Enz, C. A., Canina, L., van der Rest, J.-P. (2015): Competitive hotel pricing in Europe: An exploration of strategic positioning. Cornell Hospitality Report, 15 (2): 6-16.

Fang, B., Ye, Q., Kucukusta, D., Law, R. (2016): Analysis of the perceived value of online tourism reviews: Influence of readability and reviewer characteristics. Tourism Management, 52: 498506.

Fernández-Barcala, M., González-Díaz, M., Prieto-Rodríguez, J. (2010): Hotel quality appraisal on the Internet: a market for lemons? Tourism Economics, 16 (2): 345-360.

Gavrilović, Z., Maksimović, M. (2018): Green innovations in the tourism sector. Strategic Management, 23 (1): 36-42. 
Gronflaten, O. (2009): Predicting travelers' choice of information sources and information channels. Journal of Travel Research, 48 (2): 230-244.

Hospitality (2015): The global hotel industry and trends for 2016; $<$ http://www.hospitalitynet.org/news/4073336.html>

Ivanov, S., Zhechev V. (2012): Hotel Revenue Management: A Critical Review. Tourism: An International Interdisciplinary Journal, 60 (2): 175-179.

Ivanov, S. (2014): Hotel Revenue Management: From Theory to Practice. Várna, Bulgária, Zangador Kiadó.

Jiang, L., Erdem, M. (2018): Effects of Revenue Management Pricing Strategies on Perceived Fairness. Journal of Hospitality Marketing \& Management, 27 (4): 424-442.

Jones, P., Chen, M. M. (2011): Factors determining hotel selection: Online behaviour by leisure travelers. Tourism and Hospitality Research, 11 (1): 83-95.

Kashyap, R., Bojanic, D. C. (2000): A structural analysis of value, quality, and price perceptions of business and leisure travelers. Journal of travel research, 39 (1): 45-51.

Kim, M., Lee S.K., Roehl W.S. (2016): The effect of idiosyncratic price movements on short- and long-run performance of hotels. International Journal of Hospitality Management, 56: 78-86.

Kimes, S. E., Wirtz, J. (2015): Revenue management: Advanced strategies and tools to enhance firm profitability. Foundations and Trends in Marketing, 8 (1): 1-68.

Kotler, P. (2015): Framework for Marketing Management. Pearson Kiadó, New-Jersey, Amerikai Egyesült Államok.

Kothari, C. R. (2004): Research methodology. Methods and techniques. (Second revised edition). New Age International Publishers, New Delhi.

Law, R., Cha, I., Goh, C. (2007): Where to find the lowest hotel room rates on the internet? The case of Hong Kong. International Journal of Contemporary Hospitality Management, 19 (6): 495506.

Law, R., Leung, R., Lo, A., Leung, D., Fong, L. H. N. (2015): Distribution channel in hospitality and tourism: Revisiting disintermediation from the perspectives of hotels and travel agencies. International Journal of Contemporary Hospitality Management, 27 (3): 431-452.

Le, N. T., Pearce, D. G., Smith, K. A. (2018): Distribution channels and ownership of upmarket hotels in a transition economy. International Journal of Hospitality Management, 68: 50-58.

Lee, M. (2018): Modeling and forecasting hotel room demand based on advance booking information. Tourism Management, 66: 62-71.

Legohérel, P., Poutier, E., Fyall, A. (2013): Revenue Management for Hospitalty and Tourism. Woodeaton, Oxfor, Nagy-Britannia, Goodfellow Kiadó.

Lew, G. (2017): The importance of customer lifetime value in determining their profitability. The Business \& Management Review, 8 (4): 24.

Liu, W., Guillet, B. D., Xiao, Q., Law, R. (2014): Globalization or localization of consumer preferences: The case of hotel room booking. Tourism Management, 41: 148-157.

Marriott, Jr. J., Cross, R. (2000): Room at the revenue inn. In: Krass, P. (szerk.): Book of Management Wisdom: Classic Writings by Legendary Managers. New York, Amerikai Egyesült Államok, Wiley Kiadó, 199-208.

Martin-Fuentes, E. (2016): Are guests of the same opinion as the hotel star-rate classification system? Journal of hospitality and tourism management, 29: 126-134.

Melis, G., Piga, C. A. (2017): Are all online hotel prices created dynamic? An empirical assessment. International Journal of Hospitality Management, 67: 163-173.

Mill, R.C., Morrison, A.M. (2009): The Tourism System (6-ik kiadás). Kendall Hunt Kiadó, Amerikai Egyesült Államok.

Mohammed, A. A., Rashid, B. B., Tahir, S. B. (2017): Customer relationship management and hotel performance: the mediating influence of marketing capabilities-evidence from the Malaysian hotel industry. Information Technology \& Tourism, 17 (3): 335-361.

Morosan, C. (2014): Toward an integrated model of adoptation of mobile phones for purchasing ancillary services in air travel. International Journal of Contemporary Hospitality Management, 27 (2): 246-271. 
Nair, G. K. (2018): Dynamics of pricing and non-pricing strategies, revenue management performance and competitive advantage in hotel industry, International Journal of Hospitality Management, Online elérhető: 2018. október 24. https://doi.org/10.1016/j.ijhm.2018.10.007

Narangajavana, Y., Garrigos-Simon, F. J., García, J. S., Forgas-Coll, S. (2014): Prices, prices and prices: A study in the airline sector. Tourism Management, 41: 28-42.

Nicolau, J. L., Sharma, A. (2018): To Ban or not to ban rate parity, that is the question... or not? International Journal of Hospitality Management; Online elérhetö: 2018. augusztus 29. https://doi.org/10.1016/j.ijhm.2018.08.016

Noone, B. M., McGuire, K. A. (2014): Effects of price and user-generated content on consumers' prepurchase evaluations of variably priced services. Journal of Hospitality \& Tourism Research, 38 (4): 562-581.

Noone, B. M., Enz, C. A., Glassmire, J. (2017): Total hotel revenue management: a strategic profit perspective. Cornell Hospitality Report, 17 (8): 3-15.

Núñez-Serrano, J. A., Turrión, J., Velázquez, F. J. (2014): Are stars a good indicator of hotel quality? Assymetric information and regulatory heterogeneity in Spain. Tourism management, 42: 7787.

Oskam, J., Zandberg, T. (2016): Who will sell your rooms? Hotel distribution scenarios. Journal of Vacation Marketing, 22 (3): 265-278.

Radojevic, T., Stanisic, N., Stanic, N., Davidson, R. (2018): The effects of traveling for business on customer satisfaction with hotel services. Tourism Management, 67: 326-341.

Rafiei, H., Rabbani, M., Razmi, J., Jolai, F. (2013): Product bundle pricing in the new millennium: a literature review. International Journal of Advances in Management Science, 2 (3): 109-118.

Rondan-Cataluña, F. J., Rosa-Diaz, I. M. (2014): Segmenting hotel clients by pricing variables and value for money. Current Issues in Tourism, 17 (1): 60-71.

Schütze, J. (2008): Pricing strategies for perishable products: the case of Vienna and the hotel reservation system hrs.com. Central European Journal Operation Research, 16 (1): 43-66.

Shy, O. (2008): How to Price: A Guide to Pricing Techniques and Yield Management. Cambridge. Egyesült Királyság, Cambridge University Kiadó

Skripak, S. J. (2016): Fundamentals of Business, Pamplin College Kiadó, Virginai, Amerikai Egyesült Államok

Smith, B. C., Leimkuhler, J. F., Darrow, R. M. (1992): Yield management at American airlines. Interfaces, 22 (1): 8-31.

Szakály Z., Popp J., Kontor E., Kovács S., Pető K., Jasák H. (2017): Attitudes of the Lifestyle of Health and Sustainability Segment in Hungary. Sustainability, 9 (10): 1763.

Tan, J., Dwyer, L. (2014): Managing distribution channel conflict in the hotel industry. International Journal of Marketing \& Business Communication, 3 (1): 1-12.

TravelClick (2016): Online and mobile bookings continue to strengthen hotel performance; $<\mathrm{http}: / /$ www.hotelnewsresource.com/article89099.html $>$

Viglia, G., Mauri, A., Carricano, M. (2016): The exploration of hotel reference prices under dynamic pricing scenarios and different forms of competition. International Journal of Hospitality Management, 52: 46-55.

Vives, A., Jacob, M., Aguiló, E. (2018): Online hotel demand model and own-price elasticities: An empirical application in a mature resort destination. Tourism Economics, Published online: 2018. szeptember 14. https://doi.org/10.1177/ 1354816618800643

Wang, X. L., Yoonjoung, Heo C., Schwartz, Z., Legohérel, P., Specklin, F. (2015): Revenue management: Progress, challenges, and research prospects. Journal of Travel \& Tourism Marketing, 32 (7): 797-811.

Xiang, Z., Wang, D., O'Leary, J. T., Fesenmaier, D. R. (2015): Adapting to the internet: trends in travelers' use of the web for trip planning. Journal of Travel Research, 54 (4): 511-527.

Yavas, U., Babakus, E. (2005): Dimensions of hotel choice criteria: congruence between business and leisure travelers. International Journal of Hospitality Management, 24 (3): 359-367. 
Yilmaz, Ö., Pekgün, P., Ferguson, M. (2017): Would you like to upgrade to a premium room? Evaluating the benefit of offering standby upgrades. Manufacturing \& Service Operations Management, 19 (1): 1-18.

Yoo, M., Bai, B., Singh, A. (2018): Loyalty program effectiveness: investigating the evolution of behavioral loyalty customer liftime value over time. In: 8th Advances in Hospitality and Tourism Marketing and Management Conference, 262-273.

Zheng, C., Forgacs G. (2017): The emerging trend of hotel total revenue management. Journal of Revenue and Pricing Management, 16 (3): 238-245.

Zsidó K. E., Fenyves V. (2015): Application of „Traditional “and „New “Approach Methods in Business Performance Measurement. Cross-Cultural Management Journal, 17 (1): 51-57. 